\title{
The role of ischemic preconditioning at the gracilis muscle of rats in the early phase of reperfusion injury ${ }^{1}$
}

\author{
O papel do precondicionamento isquêmico do músculo grácil \\ de ratos na fase precoce da reperfusão
}

\author{
Ronaldo Scholze Webster², Edna Frasson Souza Montero ${ }^{3}$, Djalma José Fagundes ${ }^{4}$, Cláudio Galleano Zettler ${ }^{5}$, José Coiro ${ }^{6}$ \\ 1. Research from Post-graduation Program in Surgery and Experimentation of Federal University of São Paulo - UNIFESP -EPM. São \\ Paulo, Brazil. \\ 2. Master in Basic Sciences in Surgery and Experimentation of Federal University of São Paulo - UNIFESP- EPM. São Paulo, Brazil. \\ 3. Affiliate Professor of Surgery Department of Federal University of São Paulo and Professor of Post-graduation Program in Surgery and \\ Experimentation - UNIFESP- EPM. São Paulo, Brazil. \\ 4. Associate Professor of Surgery Department of Federal University of São Paulo and Coordinator of Post-graduation Program in Surgery \\ and Experimentation - UNIFESP- EPM. São Paulo, Brazil. \\ 5. Associate Professor of Pathology - Federal College Foundation of Porto Alegre. Rio Grande do Sul, Brazil. \\ 6. Head of Electronic Microscopy Laboratory from Lutheran University of Brazil. Rio Grande do Sul, Brazil.
}

\begin{abstract}
Purpose: Verify the role of ischemic preconditioning (IPC) in ischemia and reperfusion injury on gracilis muscle of rats. Methods: Wistar rats $(n=30)$ were distributed in three groups, I/R and IPC groups were subdivided concerning ischemia time. A near-amputation model of the posterior limb was produced by a hip joint level incision, preserving the vascular bundle and the femur bone and ischemia was induced for $2 \mathrm{~h}$ and $4 \mathrm{~h}, \mathrm{G}-\mathrm{I} 2 \mathrm{~h} / \mathrm{R}(\mathrm{n}=6)$ and G-I 4h/R (n=6), followed by $1 \mathrm{~h}$ of vascular reperfusion. The preconditioned groups, G-PCI $2 h(n=6)$ and G-PCI $4 h(n=6)$, were preceded by 3 cycles of $5 \mathrm{~min}$ of ischemia followed by $5 \mathrm{~min}$ of vascular reperfusion before sustained ischemia. In the Control Group, C-G (n=6) animals were subjected to regional approach. The analysis was done with Light Microscopy (LM). Results: The levels of fibril fragmentation were progressive in the G-I $2 \mathrm{~h} / \mathrm{R}$ ( $67 \%$ of muscle preservation) and in the G-I4 h/R ( $0 \%$ of muscle preservation). However in the group of the precondition the lesion degree being in level similar to the group controls in the $\mathrm{G}$-I $2 \mathrm{~h} / \mathrm{R}$ ( $100 \%$ of muscle preservation) while at G-I $4 \mathrm{~h} / \mathrm{r}$ occur less protection ( $67 \%$ of muscle preservation). The degree of tissue inflammatory reaction was worst at G-I $4 \mathrm{~h} / \mathrm{R}$ ( $0 \%$ without inflammation signals) than at G-I $2 \mathrm{~h} / \mathrm{R}$ ( $50 \%$ without inflammation signals); while in the precondition group G-IPC-2h (83\% without inflammation signals) was better than the G-IPC-4h (67\% without inflammation signals). The vascular stasis was absent only in $17 \%$ of the G-I $4 \mathrm{~h} / \mathrm{R}$ and in $33 \%$ of the G-I $2 \mathrm{~h} / \mathrm{R}$. In precondition group, however, the vascular stasis was absent in 33\% at G-IPC $2 \mathrm{~h}$ and absent in 50\% at G-IPC 4h. Conclusion: The IPC showed, in an earlier phase, a benefic role at I/R derived injury on gracilis muscle of rats, as proven for the largest preservation of the fibers muscular, smaller inflammatory reaction and smaller vascular stasis.
\end{abstract}

Key words: Reperfusion Injury. Reperfusion. Skeletal, Muscle. Transplants. Rats.

\section{RESUMO}

Objetivo: Verificar o papel do precondicionamento isquêmico (PCI) na lesão de isquemia e reperfusão (I/R) do músculo grácil de ratos. Métodos: Trinta ratos Wistar foram distribuídos em três grupos, sendo G-I/R e G-PCI subdivididos em relação ao tempo de isquemia. Produziu-se modelo de quase-amputação do membro posterior por meio de uma incisão, preservando o feixe vascular e o osso femoral, induzindo-se isquemia por $2 \mathrm{~h}$ e $4 \mathrm{~h}, \mathrm{G}-\mathrm{I} 2 \mathrm{~h} / \mathrm{R}$ (n=6) e G-I 4h/R (n=6), seguida por $1 \mathrm{~h}$ de reperfusão. Os Grupos Precondicionados, G-PCI $2 \mathrm{~h}(\mathrm{n}=6)$ e G-PCI $4 \mathrm{~h}(\mathrm{n}=6)$, foram precedidos por 3 ciclos de $5 \mathrm{~min}$ de isquemia seguidos de $5 \mathrm{~min}$ de reperfusão, antes da isquemia sustentada. No Grupo Controle, G-C (n=6) realizou-se apenas a abordagem regional. As avaliações morfológicas foram realizadas por meio de Microscopia Óptica (MO) para avaliação da desestruturação miofibrilar, processo inflamatório e estase venosa no tecido do músculo grácil. Foram atribuídos escores semi-quantitativos às variáveis estudadas. Resultados:Houve preservação miofibrilar de 76\% em GI2h/R e 0\% em G-I4h/R; G-IPC 2h a preservação foi de 100\% e de 67\% em G-IPC 4h. A reação inflamatória foi mais acentuada em G-I 4h (100\% com inflamação) do que em G-I2h (50\%);G-IPC 2h apresentou 82\% sem inflamação e G-IPC 4h apresentou 67\% sem inflamação. A estase vascular esteve ausente em 17\% do G-I 4h e em 33\% do G-I 2h; em G-IPC 2h esteve ausente em33\% e em G-IPC 4h em 50\%. Conclusão: O PCI mostrou, em uma fase inicial, papel benéfico na lesão de I/R no músculo grácil de ratos, comprovado pela maior preservação das fibras musculares, menor reação inflamatória e menor estase venosa.

Descritores:Traumatismo por Reperfusão. Reperfusão. Músculo Esquelético. Transplantes. Ratos. 


\section{Introduction}

The use of microsurgical flaps, such as the ones from the gracilis muscle, has brought a revolution in the treatment of complex tissue defects. The gracilis muscle not only allows a quantity of tissue fit for the reconstruction, but it can also exert, through microneurorrhaphy, complementary muscular contractility to the reparation, being beneficial towards ailments such as facial paralisy ${ }^{1}$. However, the microsurgical transference sometimes causes prolonged muscular ischemia, and it means a significant injury to tissue compromising it viability ${ }^{2}$. Some protection strategies have been used for the preservation of the flaps, amongst them the ischemic preconditioning (IPC). The ischemic preconditioning is a surgical alternative that employs short cycles of ischemia followed by reperfusion, previously to a sustained ischemia. The first studies conducted with IPC involved the myocardium. In 1984, Neely and Grotyohann³, using the myocardium of rabbits, showed that a short period of ischemia, previously to the sustained cardiac ischemia, produced a protective effect against the cardiac injury of ischemia-reperfusion (I/R). Afterwards, Murry et al. ${ }^{4}$, using the myocardium muscle of dogs, could register the protective effect of IPC through a number of experiments, when the term ischemic preconditioning was definitively divulged. From these experiments, the IPC has been used in studies related to different organs and tissues, including in the skeletal muscle $e^{5,6}$. It was observed in the skeletal muscle that, relating with the myocardium, it was necessary more ischemia-reperfusion cycles to obtain a threshold of protection $^{7}$. The maintenance mechanism of the cellular oxidation, the reduction of the production of reactive oxygen specimen (ROS) and the preservation of the integrity and functioning of the cellular membrane, through different mediators, are being studied as probable action mechanisms of the IPC ${ }^{8}$. Although previous studies for the IPC evaluation in skeletal muscles were conducted, the gracilis muscle of rats only recently started to be evaluated for its protection by IPC. Zhang et al. ${ }^{9}$ studied the effects of IPC in the late phase of vascular reperfusion of the gracilis muscle of rats demonstrating positive effects in the tissue preservation. The gracilis muscle can have a different behavior from other muscle groups previously analyzed for IPC and there is a lack of studies on the early phase of the ischemia and reperfusion process. This research was developed with the goal to elucidate the cellular alterations of the early phase of ischemia and reperfusion of the gracilis muscle of rats subjected to IPC.

\section{Methods}

The present study has been approved by the Committee of Ethics in Research of the Hospital São Paulo - UNIFESP - EPM, under the register number 1095/03, ratified by the Committee of Ethics in Research in Human Beings and Animals of the Lutheran University of Brazil Rio Grande do Sul - ULBRA-RS, under the register number 2003-006 A. Thirty Wistar male rates, 250 to 350 g, 3 to 4 months old, raised in a conventional animal colony from ULBRA-RS, were kept in controlled conditions of light (clear cycle from $7 \mathrm{~h}$ to $19 \mathrm{~h})$, temperature $\left(22-24^{\circ} \mathrm{C}\right)$ and receiving standard food and water ad libitum. The animals were distributed at random in three groups according to the procedure conducted: control group (G-C: $n=6)$, ischemiareperfusion group (G-I/R: $n=12)$ and ischemic preconditioning group (G-IPC: $n=12$ ). The $I / R$ and IPC groups were subdivided taking into consideration the ischemia time ( $2 \mathrm{~h}$ and $4 \mathrm{~h}$ ), originating $\mathrm{G}-\mathrm{I} 2 \mathrm{~h} / \mathrm{R}(\mathrm{n}=6), \mathrm{G}-\mathrm{I}$ 4h/R (n=6), G-IPC $2 \mathrm{~h}(\mathrm{n}=6)$ and G-IPC $4 \mathrm{~h}$. The animals were kept fasting for solid foods during daytime during a period of three hours prior to the operation procedures and had their weight checked before they entered the procedure room, to calculate the anesthetic dose. They were brought to the operation room in plastic boxes appropriated for transportation and subjected to pre-anesthesia in a chamber saturated with diethylic ether, with the subsequent administration of atropine $0,044 \mathrm{mg} . \mathrm{Kg}^{-1}$, through the intraperitoneal way (IP), fulfilling a latency time of 10 minutes until the use of the anesthesic medication. The administered anesthesia was the combination between ketamine chloridrate (Ketalar ${ }^{\circledR}$ ) 50mg. $\mathrm{Kg}^{-1}$ and xylazine chloridate (Anasedan $^{\circledR}$ ) 10mg. Kg ${ }^{-1}$ IP. The anesthesic plan was evaluated through the following parameters: respiratory frequency, cardiac frequency, corneal reflex and caudal pinch reflex. The anesthesia complementation was performed with half the initial dose in an average time of 1h30min after induction, being helped by the parameters of the anesthetic plan. They were subjected to epilation around the left posterior limb in the area of the hip articulation in the left posterior limb, followed by antisepsis of the skin with a solution of polivynilpirrolidone (topic PVPI ${ }^{\circledR}$ ) at $1 \%$. It was used, for the execution of the surgical procedure, a binocular magnifying glass (Heine ${ }^{\circledR}$ ) with magnifying capacity of 3,5X. The skin, subcutaneous, and thigh musculature, around the hip articulation, was incised by plans, circumferentially, with a scalpel, preserving the femoral bone and the neurovascular femoral bundle. The femur periosteum was removed, below the hip articulation, by an extension of 0.5 $\mathrm{cm}$. The hemostasis was done by compression. The tissue dissection was done next to the neurovascular bundle with the help of nippers and microsurgical scissors, and later on, with the use of delicate traction of the bundle sheath, it were individualized the arterial, vascular and nervous components. The nervous component was divided for simulating the microsurgical transference. In the G-C, it was performed, after $30 \mathrm{~min}$ following the vascular isolation, the collection of fragment of the gracilis muscle for analysis under light microscopy. In the G-I/R, after 30min following the vascular isolation, it was proceeded the ischemic interval proposed according to the subgroups, $2 \mathrm{~h}$ or $4 \mathrm{~h}$, followed by $1 \mathrm{~h}$ of vascular reperfusion. The vascular microclamp $\left(\mathrm{ASSI}^{\circledR}\right)$, used in the interruption of the blood flow, had pressure graduated for vessels between 0.5 and $1.5 \mathrm{~mm}$ of external diameter. In the G-IPC, it was applied three ischemia cycles of $5 \mathrm{~min}$, intercalated with the same period of arterial reperfusion before the ischemia period, $2 \mathrm{~h}$ or $4 \mathrm{~h}$, and sustained reperfusion for $1 \mathrm{~h}$ (Figures 1 and 2).

Afterwards it was collected, in bottles containing formalin at $10 \%$, a fragment of the gracilis muscle, with an approximate dimension of $1.5 \times 1.0 \times 0.3 \mathrm{~cm}$, for posterior analysis. After the obtainment of the muscular fragment it was performed the euthanasia of the animal through an 
endovenous injection of anesthesic, ketamine chloridate 150mg. $\mathrm{Kg}^{-1}$ and xylazine chloridate $30 \mathrm{mg} . \mathrm{Kg}^{-1} \mathrm{IV}$. The analysis under light microscopy was conducted in the Research and Diagnosis Institute of the Santa Casa de Porto Alegre - RS. The fixated material was subjected to dehidratation in ethylic alcohol at 70\%, 95\%, 100\%; clearing with Xilol; impregnation with paraffin molten at $60^{\circ} \mathrm{C}$; inclusion in rectangular moulds; cut by microtomes (Leica ultracut ${ }^{\circledR}$ UCT RM2025) with thickness of 5ìm, discardable plates model 818 size $\mathrm{C}$ and coloration by Hematoxiline Eosine (HE). The analysis was done through a light microscope (Olympus ${ }^{\circledR}$ BX40F40), with zoom between 100 and $1000 \mathrm{x}$ in a system of image acquisition through digital system (Samsung aerospace-ICONOS ${ }^{\circledR}$ - Imaging Systems) and computer processing in an equipment with processor with $2.4 \mathrm{Gz}$ speed (Athlon ${ }^{\circledR}$ ), with the image diagnosis program (SDI ${ }^{\circledR}$ - System of image diagnosis, developed by Defferari Informatica Ltda ${ }^{\circledR}$ ).
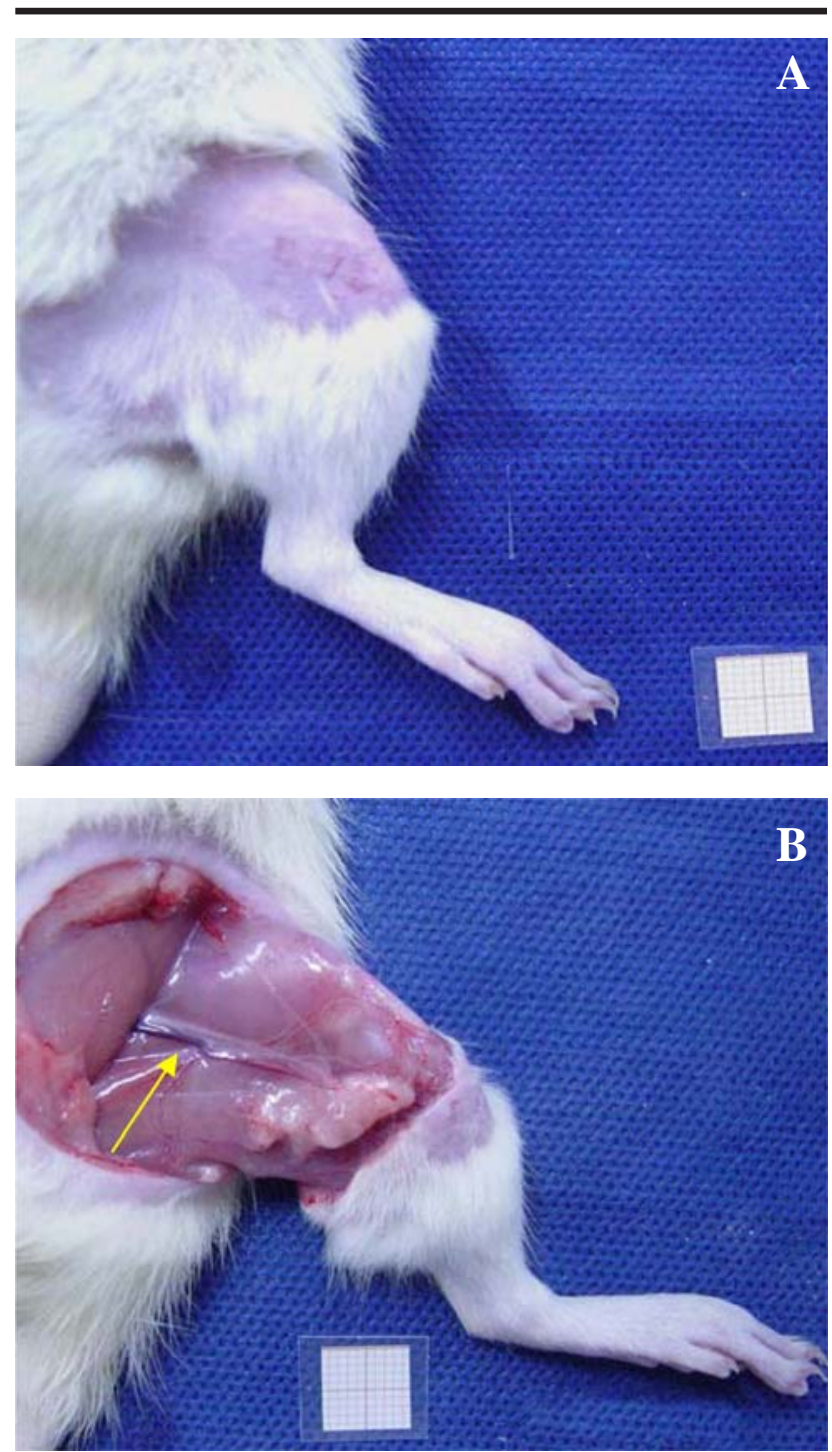

FIGURE 1 - Photography of the left posterior paw of the animal after epilation (a) and after the surgical preparation for the experiment (b). The arrow indicates the localization of the neurovascular femoral bundle

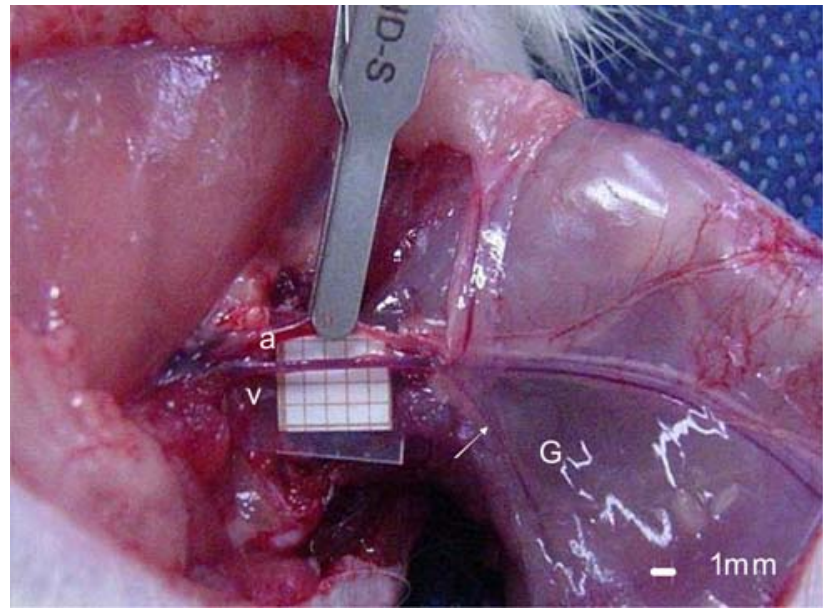

FIGURE 2 - Photography showing the model of nearamputation of the left posterior paw of the animal and identification of the vascular bundle. a: femoral artery occluded with vascular dilatation close to the clamp and lack of distal blood flow. It can be noted the difference of colour of the limb in comparison to the abdomen. v: femoral vein, G: gracilis muscle. The arrow indicates the position of the vascularization of the gracilis muscle

It was evaluated the general aspects of the tissue reaction to ischemia and vascular reperfusion, with special attention to fibril fragmentation, to the presence of inflammatory reaction and vascular stasis, being semiquantified in: 0 (lack or discreet presence $-25 \%$ or less), 1 (moderate presence -26 to $50 \%$ ) and 2 (intense $-51 \%$ or upper), according to its occurrence. The standard of minor lesion intensity (0) was established in the animals which were less assailed in the G-C and the major degree of considered lesion (2) was based on the animals with the most intense alterations, identified as belonging to G-I 4h/ $\mathrm{R}$. The intermediary level of assail (1) was adopted when the lesional characteristics were found between the magnitudes observed in the described groups. It was obtained, thus, the percentage of animals, by analysis subgroups, in relation to the level of intensity of the lesions, looking to establish the influence of the ischemia time in the intensity of the observed lesions. The qui-square test was performed $(\mathrm{p}<0.05)$ for all groups.

\section{Results}

It was verified under light microscopy that, in relation to the control group (Lesion Degree 0: 100\%), the G-I 2h/R and $\mathrm{G}-\mathrm{I} 4 \mathrm{~h} / \mathrm{R}$, in a progressive manner and proportional to the ischemia time, presented fibril fragmentation (Lesion Degree 0: 67\% and 0\%, respectively) (Figures 3 and 4; Table 1). It was evidenced the biggest level of tissue inflammatory reaction and vascular stasis in the G-I 4h/R (Lesion Degree 0: $0 \%$ ) in relation to the other groups (Figure 5 and 6; Table $2)$. The ischemic preconditioning has attenuated the progressive cellular alterations characterized by the fibril fragmentation (Lesion Degree 0: IPC $2 \mathrm{~h}=100 \%$; IPC $4 \mathrm{~h}=$ 
67\%) and inflammatory reaction (Lesion Degree 0: IPC $2 \mathrm{~h}=$ 83\%; IPC $4 \mathrm{~h}=67 \%$ ), $\mathrm{p}=0,038$ and 0,041 respectively, (Tables 1 and 2; Figures 4 and 6). There were no benefits of IPC in relation to the vascular findings, comparing to the G-I/R (Table 3; Figures 7 and 8).
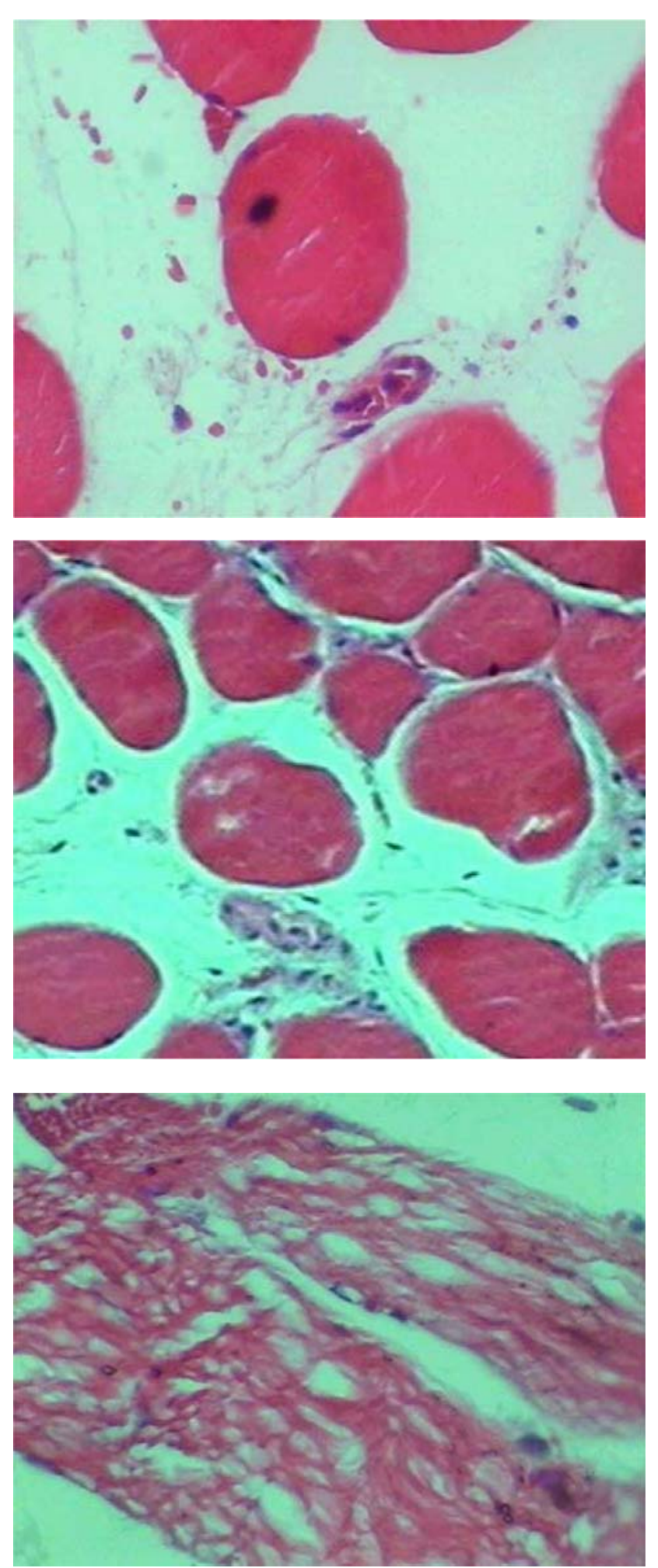

FIGURE 3 - Photomicrograpies showing the fibril fragmentation intensity under optic microscopy. a: Degree (GC). $\underline{b}$ : Degree 1 (G-I 2h/R). c: Degree 2 (G-I 4h/R). F: Muscular fiber. V: Vacuoles. HE, zoom of 400X
TABLE 1 - Data referent to the presence of fibril fragmentation classified as Degree 0 (lack or discreet presence $25 \%$ or less), Degree 1 (moderate presence -26 to $50 \%$ ) and Degree 2 (intense $-51 \%$ or upper) in the control group (G-C) ischemia/reperfusion group (G-I 2h/R and G-I 4h/R) and IPC group (G-IPC 2h and G-IPC 4h)

\begin{tabular}{lcccc}
\hline GROUPS & $\begin{array}{c}\text { Degree } \\
0\end{array}$ & $\begin{array}{c}\text { Degree } \\
1\end{array}$ & $\begin{array}{c}\text { Degree } \\
2\end{array}$ & $\begin{array}{c}\text { Percentage of } \\
\text { Degree 0 }\end{array}$ \\
\hline CONTROL & 6 & 0 & 0 & 100 \\
I 2h / R & 4 & 2 & 0 & 67 \\
IPC 2h & 6 & 0 & 0 & 100 \\
I 4h /R & 0 & 2 & 4 & 0 \\
IPC 4h & 4 & 2 & 0 & 67 \\
\hline
\end{tabular}

For the statistic analysis the Lesion Degree 1 and 2 were added up forming the degree 1 and the subgroups subjected to $2 \mathrm{~h}$ and $4 \mathrm{~h}$ ischemia were placed together as one group, taking into consideration the kind of intervention which was carried out, resulting in the $I / R$ and IPC groups.

TABLE 2 - Data referent to the presence of tissue inflammatory reaction classified as Degree 0 (lack or discreet presence - up to 25\%), Degree 1 (moderate presence - 26 to 50\%) and Degree 2 (intense above $50 \%$ ), in the control group (G-C), ischemia/ reperfusion group ( $\mathrm{G}-\mathrm{I} 2 \mathrm{~h} / \mathrm{R}$ and $\mathrm{GI} 4 \mathrm{~h} / \mathrm{R})$ and group IPC (G-IPC $2 h$ and G-IPC 4h)

\begin{tabular}{lcccc}
\hline GROUPS & $\begin{array}{c}\text { Degree } \\
0\end{array}$ & $\begin{array}{c}\text { Degree } \\
1\end{array}$ & $\begin{array}{c}\text { Degree } \\
2\end{array}$ & $\begin{array}{c}\text { Percentage of } \\
\text { Degree 0 }\end{array}$ \\
\hline CONTROL & 6 & 0 & 0 & 100 \\
I 2h / R & 3 & 1 & 2 & 50 \\
IPC 2h & 5 & 1 & 0 & 83 \\
I 4h / R & 0 & 2 & 4 & 0 \\
IPC 4h & 4 & 2 & 0 & 67 \\
\hline
\end{tabular}

For the statistic analysis the lesion degree 1 and 2 were added up, forming the degree 1 and the subgroups subjected to $2 \mathrm{~h}$ and $4 \mathrm{~h}$ ischemia were placed together in as one group, taking into consideration the kind of intervention which was carried out, resulting in the I/R and IPC groups.

TABLE 3 - Data referent to the presence of vascular stasis classified as Degree 0 (lack or discreet presence - up to 25\%), Degree 1 (moderate presence 26 to $50 \%$ ) and Degree 2 (intense - above 50\%), in the control group (G-C), ischemia/ reperfusion group (G-I 2h/R and G-I 4h/R) and group IPC (GIPC $2 \mathrm{~h}$ and $\mathrm{G}$-IPC $4 \mathrm{~h}$ )

\begin{tabular}{lcccc}
\hline GROUPS & $\begin{array}{c}\text { Degree } \\
0\end{array}$ & $\begin{array}{c}\text { Degree } \\
1\end{array}$ & $\begin{array}{c}\text { Degree } \\
2\end{array}$ & $\begin{array}{c}\text { Percentage of } \\
\text { Degree 0 }\end{array}$ \\
\hline CONTROL & 6 & 0 & 0 & 100 \\
I 2h /R & 2 & 2 & 2 & 33 \\
IPC 2h & 2 & 3 & 1 & 33 \\
I 4h / R & 1 & 2 & 3 & 17 \\
IPC 4h & 3 & 3 & 0 & 50 \\
\hline
\end{tabular}

For the statistic analysis the lesion degree 1 and 2 were added up, forming the degree 1 and the subgroups subjected to $2 \mathrm{~h}$ and $4 \mathrm{~h}$ ischemia were placed together in as one group, taking into consideration the kind of intervention which was carried out, resulting in the I/R and IPC groups. 


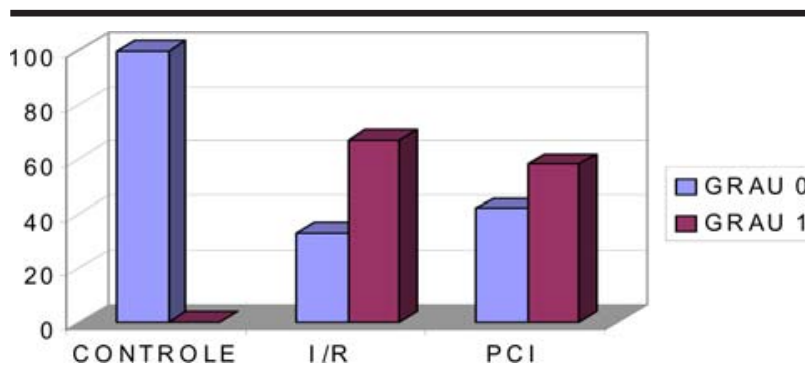

FIGURE 4 - Percentage distribution of the animals as to the intensity of the fibril fragmentation according the groups. Qui-square Test* $(\mathrm{p}=0,038)$
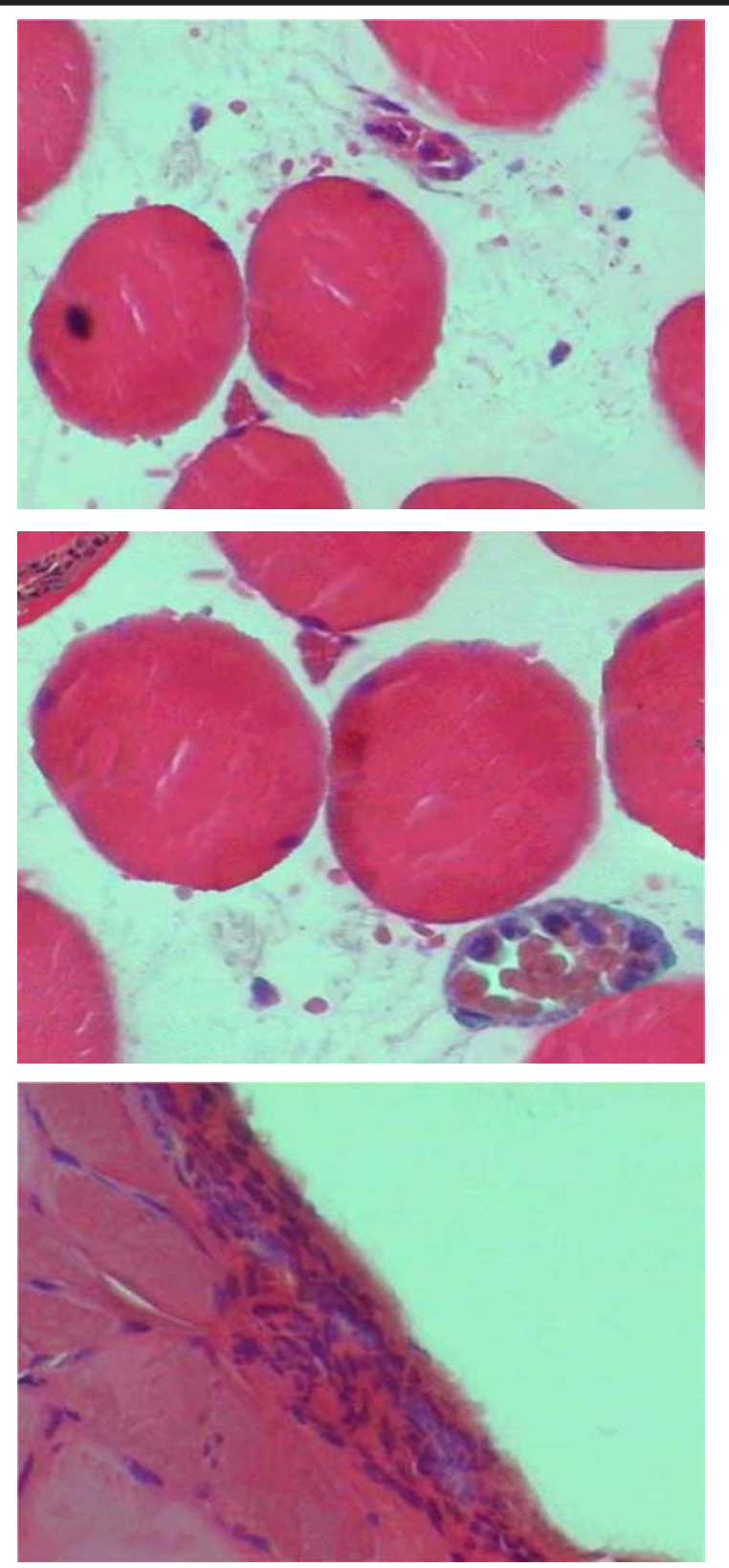

FIGURE 5-Photomicrographies showing the intensity of tissue inflammatory reaction under light microscopy: $\underline{a}$ : Degree 0 (G-C) lack or discreet presence. $\underline{b}$ : Degree $1(\mathrm{G}-\mathrm{I}$ 2h/R) moderate presence. $\underline{\text { : }}$ Degree 2 (G-I 4h/R) intense presence. F: muscular fiber. I: Inflammatory infiltrated. V: neutrofilic vasculitis. HE, zoom of $400 X$

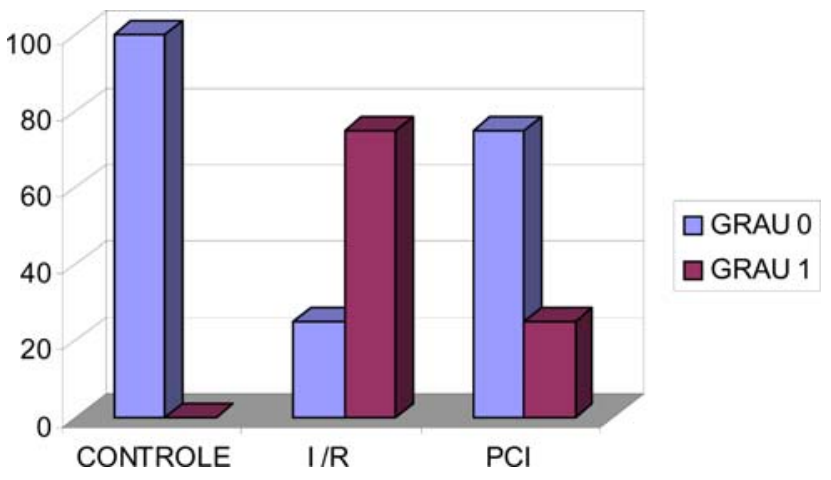

FIGURE 6 - Percentage distribution of the animals as to the intensity of the tissue inflammatory reaction according to the groups. Qui-Square Test * $(p=0,041)$
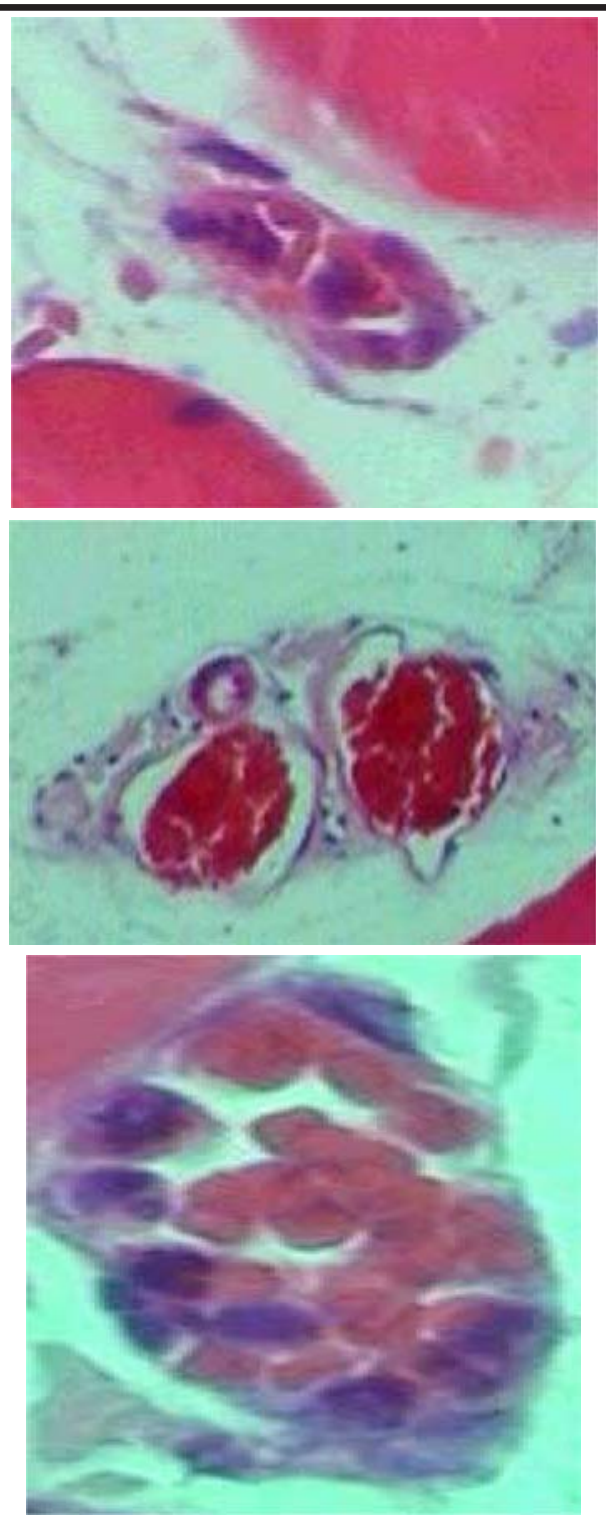

FIGURE 7 - Photomicrographies showing the intensity of the vascular stasis under optic microscopy. a. Degree 0 (G-C) normal capillary, preserved endothelium. $\underline{b}$ : Degree $1(\mathrm{G}-\mathrm{I} 2 \mathrm{~h} / \mathrm{R})$ moderate stasis. c: Degree 2 (G-I 4h/R) accentuated stasis. C: capillary, I: margined neutrophils. Circle in the figure c delimits capillary in detail. HE, zoom of $400 \mathrm{X}$ 


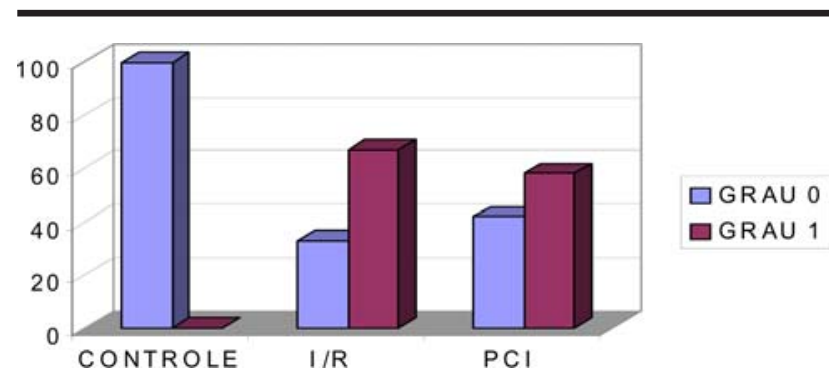

FIGURE 8 - Percentage distribution of the animals as to the intensity of the vascular stasis according to the groups. Qui-Square Test: findings were non-significant

\section{Discussion}

It is usually accepted a success level between 90 and $95 \%$ in microsurgical transplants. However, around $4 \%$ to $26 \%$ of the final numbers of cases subjected to the tissue transference through microsurgery are submitted to a surgical review because of vascular intercurrences that can be related to the ischemia-reperfusion phenomenon ${ }^{2}$. The IPC has a very important action in the attenuation of this kind of lesion and has the advantage of its possibility of use in the current surgical period, with no need of additional surgical procedures, and with no collateral effects from the use of drugs applied to raise the tissue viability ${ }^{10}$.

The gracilis muscle has been used as an object of study in various animal experiment models related to muscular transferences. However, the combination between the evaluation of this muscle and the ischemic preconditioning has only recently been conducted by Zhang et al. ${ }^{9}$, analyzing the nitric oxide as a possible IPC mediator. Stembergh et al. ${ }^{11}$ have verified that the kind of fiber and the location of the muscular groups are not directly related to the lesion degree caused by the ischemia and reperfusion phenomenon. There is, therefore, a special interest in the mapping of the behavior of the gracilis muscle facing the ischemic preconditioning in the ischemia/reperfusion lesion.

The tissue transferences subject the muscle to sustained vascular privation with subsequent reperfusion, with the possible occurrence of a significant lesion. The lesions can be reversible or irreversible according to the duration of the stimulus. Once established the irreversible lesion of the cell, the cellular death manifests itself through necrosis or apoptosis. The necrosis is the most common kind of cellular death after exogenous stimulus, such as ischemia; it manifests itself through intense tumefaction or cell rupture, denaturation and coagulation of cytoplasm proteins and the degradation of cellular organelles. There is a preponderant inflammatory component. The apoptosis happens when the cell dies due to the activation of a program of cell removal without the activation of a inflammatory process. The cellular elimination is based on DNA and the cellular fragmentation. The condemned cells are removed with minimal damage to the surrounding tissue $^{12}$.
This research showed that levels of fibril fragmentation (Table 1 and Figures 4 and 5) were progressive in the $\mathrm{G}-\mathrm{I} 2 \mathrm{~h} / \mathrm{R}$ ( $67 \%$ of muscle preservation) and in the G-I4 h/R ( $0 \%$ of muscle preservation). However in the group of the precondition the lesion degree being in level similar to the group controls in the G-I $2 \mathrm{~h} / \mathrm{R}(100 \%$ of muscle preservation) while at G-I $4 \mathrm{~h} / \mathrm{r}$ occur less protection (67\% of muscle preservation). The degree of tissue inflammatory reaction (Table 2 and Figures 6 and 7) was worst at G-I 4h/R ( $0 \%$ without inflammation signals) than at G-I 2h/R (50\% without inflammation signals); while in the precondition group G-IPC-2h (83\% without inflammation signals) was better than the G-IPC4h (67\% without inflammation signals). The vascular stasis (Table 3 and Figures 8 and 9) was absent only in $17 \%$ of the G-I $4 \mathrm{~h} / \mathrm{R}$ and in $33 \%$ of the G-I $2 \mathrm{~h} / \mathrm{R}$. In precondition group, however, the vascular stasis was absent in 33\% at G-IPC $2 \mathrm{~h}$ and absent in 50\% at G-IPC $4 \mathrm{~h}$.

So, the findings under light microscopy allowed the verification of proportionality between the ischemia time and the tissue injury, and by other hand allowed the benefits of precondition procedure in protecting the skeletal muscle against the ischemia-reperfusion phenomenon. It is important to highlight the inflammatory findings observed at G-I 4h/R. Although the goal of the study is the early phase of vascular reperfusion, the presence of tissue inflammatory reaction can be an indication of an evolution to an irreversible lesion like necrosis. The morphologic preservation of the musculature of G-IPC 4h, together with the lack of inflammatory reactions, showed a bigger potential of tissue recuperation in this group. The fact is confirmed by a study conducted by Kruel et al. ${ }^{13}$, who have verified irreversible alterations in the muscle of dogs subjected to more than $2 \mathrm{~h}$ of sustained ischemia. Labbe et $\mathrm{al}^{14}$ observed $30,3 \%$ of necrosis of the gracilis muscle of dogs subjected to 4 h sustained ischemia, in contrast with $2 \%$ in the group subjected to $2 \mathrm{~h}$ of ischemia.

It is identified in the G-I $4 \mathrm{~h} / \mathrm{R}$ a tendency to the accumulation of neutrophils in endovascular and perivascular sites. The findings were compatible with important endothelial lesions. It was not identified in the G-IPC 4h such occurrences, suggesting the attenuation of vascular lesions.

The IPC was able to diminish the adhesion and migration of leucocytes in a study conducted by Akimitsu et al. ${ }^{15}$. The adhesion and migration of leucocytes are related to the non-vascular reperfusion phenomenon and the failure of muscular transplants, having a connection with I/R lesions. The mechanism of IPC was not yet clear but it, with no doughty, protected the skeletal muscle from injury of ischemia/reperfusion events.

\section{Conclusion}

The ischemic preconditioning promoted the protection of the gracilis muscle of rats against the ischemia and vascular reperfusion lesion, in the early phase of reperfusion, according to the morphologic evaluation at light microscopy. 


\section{References}

1. Buncke HJ, Buncke GM, Kind GM, Buntic RF, Brooks D, Chin BT. Cross-facial and functional muscle transplantation for longstanding facial paralysis. Clin Plast Surg. 2002; 29:551-66.

2. Kerrigan CL, Stotland MA. Ischemic reperfusion injury: a review. Microsurgery. 1993; 14:165-75.

3. Neely JR, Grotyohann LW. Role of glycolytic products in damage to ischaemic miocardium. Circ Res. 1984; 55:816-24.

4. Murry CE, Jennings RB, Reimer KA. Preconditioning with ischemia: a delay of lethal cell injury in ischemic myocardium. Circulation. 1986; 74:1124-36.

5. Montero EFS, Quireze Jr C, d'Oliveira DMR. Bile duct exclusion from selective vascular inflow occlusion in rat liver: role of ischemic preconditioning and $\mathrm{N}$ acetylcysteine on hepatic reperfusion injury. Transplant Proc. 2005; 37(1):425-7.

6. Centurion S, Brisotti JL, Oliveira GR, Tolentino E, Pacheco EG, Oliveira AF, Silva Jr., O. de C. Avaliação da função mitocondrial do fígado submetido à isquemia parcial com e sem precondicionamento isquêmico. Acta Cir Bras. 2001; 16(Suppl 1):61-2.

7. Pang CY, Yang RZ, Zhong A, Xu N, Boyd B, Forrest $\mathrm{CR}$. Acute ischemic preconditioning protects against skeletal muscle infarction in the pig. Cardiovasc Res. 1995; 29:782-8.
8. Gürke L, Mattei A, Chaloupka K Marx A, Sutter PM, Stierli P, Harder F, Heberer M. Mechanisms of ischemic preconditioning in skeletal muscle. J Surg Res. 2000; 94:18-27.

9. Zhang F, Oswald T, Holt J, Gerzenshtein J, Lei MP, Lineaweaver WC. Regulation of inducible nitric oxide synthase in ischemic preconditioning of muscle flap in a rat model. Ann Plast Surg. 2004; 52(6):609-13.

10. Bushell AJ, Klenerman L, Taylor S, Taylor S, Davies H, Grierson I, Helliwell TR, Jackson MJ. Ischaemic preconditioning of skeletal muscle-protection against the structural changes induced by ischaemia/reperfusion injury. J Bone Joint Surg. 2002; 84-B:1184-8.

11. Sternbergh III WC, Adelman B. Skeletal muscle fiber type does not predict sensitivity to postischemic damage. J Surg Res. 1992; 53:535-41.

12. Eefting F, Rensing B, Wigman J. Role of apoptosis in reperfusion injury. Cardiovasc Res. 2004; 61:414-26.

13. Kruel G, Xavier CAM, Paulin JBP, Gonçalves RP. Efeitos da isquemia sobre o músculo esquelético: estudo experimental em cães. Rev Bras Ortop. 1981; 16(3)85-90.

14. Labbe R, Lindsay T, Walker PM. The extent and distribution of skeletal muscle necrosis after graded periods of complete ischemia. J Vasc Surg. 1987; 6:152-7.

15. Akimitsu T, Gute DC, Korthuis RJ. Ischemic preconditioning attenuates postischemic leukocyte adhesion and emigration. Am J Physiol. 1996; 271:2052-9.

\section{Correspondence:}

Ronaldo Scholze Webster

Rua Antão de Farias, 99/402

90035-210 Porto Alegre-RS Brazil

Phone: (5551)3311-0075

rswebster@turbo.com.br
Conflict of interest: none Financial source: none

Received: October 06, 2005

Review: November 09, 2005

Accepted: December 11, 2005

\section{How to cite this article:}

Webster RS, Montero EFS, Fagundes DJ, Zettler CG, Coiro J. The role of ischemic preconditioning at the gracilis muscle of rats in the early phase of reperfusion injury. Acta Cir Bras. [serial on the Internet] 2006 Mar-Apr;21(2). Available from URL: http://www.scielo.br/acb 